\title{
ИСЕЛЕНИЦИ-ПОВРАТНИЦИ: НОВА ПЕРСПЕКТИВА НА МИГРАЦИСКИТЕ ИСТРАЖУВАЊА ВО МАКЕДОНИЈА
}

\section{Кратка содржина}

Миграчиските текови на територијата на Македонија се развивале и менувале низ историските периоди. По распадот на Југославија, иселеничките движења од Македонија се разликуваат значително од традииионалните обличи на миграчија. Најкарактеристични примери се емиграчијата на висококвалификувани и образовани лица или одлив на мозочи, како и миграчиските текови и трендови предизвикани од воведувањето и либерализачијата на визниот режим во Европската Унија и зголемената мобилност на населението предизвикана од ефектите на глобализачијата.

Покрај овие иселенички движења, постои и обратен миграчиски прочес, односно враќање на иселениците во земјата на потекло. Иако бројот на иселениците повратници не го надминува оној на отселените граѓани од Република Македонија, сепак, го поттикнува интересот за истражување.

Во овој труд ќе бидат анализирани придобивките на враќањето на иселеничите и нивната улога во македонското општество и ќе бидат изнесени неколку примери на успешни иселеници повратници и нивните економски дејности во Македонија. Истражувањето, покрај презентирањето на досегашните квалитативни резултати, има цел да поттикне понатамошни истражувања во областа, како и да отвори дебата за миграчиските проблеми со кои се соочува Република Македонија.

Клучни зборови: ИСЕЛЕНИЦИ-ПОВРАТНИЦИ, МИГРАЦИЈА, РЕПУБЛИКА МАКЕДОНИЈА

\section{Вовед}

Од своето осамостојување во 1991 година, во текот на долгиот транзициски период кој трае повеќе од две декади, Република Македонија се соочува со зголемено привремено и трајно иселување на своето население, вклучувајќи феномени како одлив на мозоци и миграција на младата популација. Проблемите предизвикани од постојаните бранови на емиграција биле и се предмет на дискусија во академските кругови, политичките дебати и економските анализи. Бројни се последиците што ги предизвикува овој феномен врз социодемографските услови на државата: зголемена депопулација на селата, промена на структурата на семејствата (одвоено живеење на брачните партнери), зголемен број за апликација на странски патни исправи, намалено младо работоспособно население. 
Политичката и економската нестабилност во Република Македонија, како и постојано високата стапка на невработеност (околу $30 \%$ во последните две декади според Државниот завод за статистика на Република Македонија) го поттикнуваат дополнително привременото или трајното иселување од нашата држава. Сепак, овој феномен не е единствено едностран. Покрај горенаведените иселенички движења, постои и обратен миграциски процес, односно враќње на иселениците во земјата на потекло. Иако бројот на иселениците повратници не го надминува оној на отселените граѓани од Република Македонија, сепак, го поттикнува интересот за истражување. Од овие причини, се одлучивме да направиме мало квалитативно истражување за иселениците-повратници во Македонија со цел да се испита можноста за понатамошно поголемо квантитативно истражување. Во овој труд ќе бидат изнесени анализите на податоците од истражувањето спроведено во текот на август и септември 2015 година и април и мај 2016 година во Скопје и опфаќа структурирани индивидуални интервјуа со 13 испитаници.

Појдовната идеја беше да се интервјуираат единствено прва генерација иселеници-повратници, но во текот на истражувањето се појави нова категорија Македонци родени во странство (втора генерација иселеници-повратници) и тие беа вклучени во истражувањето, бидејќи делат заеднички карактеристики со профилот на испитаниците, како што се, на пример, пул-факторите (фактори кои ги привлекуваат луѓето на одредено место) за враќање во Македонија (Lee, 1966).

\section{Иселеници-повратници}

Антрополошките, етнолошките и социолошките науки ретко ја изучуваат темата на иселеници-повратници одделно и вообичаено ја вклучуваат во пошироки истражувања за миграциски движења. Проблематиката е запоставена во научните трудови, најчесто бидејќи бројот на иселеници-повратници се смета за статистички ирелевантен (Seferagić, 1977).

Според дефиницијата на Бирото за статистика на Обединетите нации, иселеник-повратник претставува „лице кое се враќа во земјата на потекло откако бил меѓународен мигрант (без разлика дали престојот бил краткорочен или долгорочен) во друга држава и планира да остане во својата земја барем една година“ (Dumont \& Spielvogel, 2008: 164).

Постојат повеќе категории повратна миграција, во зависност од тоа во колку држави мигрира иселеникот и дали враќањето е етапно или непосредно. Во овој труд ќе биде анализирана првата категорија иселеници-повратници, односно оние што мигрирале во една држава и се враќаат во својата земја на потекло - Македонија. ${ }^{1}$ Останати случаи на повратна миграција опфаќаат миграција од земјата на раѓање во држава А и потоа миграција од држава А во држава Б. Враќањето може да биде непосредно од држава Б во земјата на раѓање (втора категорија) или, пак, етапно од држава Б во држава А и потоа од држава А во земјата на раѓање (трета категорија).

\footnotetext{
1 Земја на раѓање е заменета со земја на потекло за вклучување на двете категории испитанищи.
} 
Слика 1: Повратна емиграција (прва категорија) ${ }^{2}$

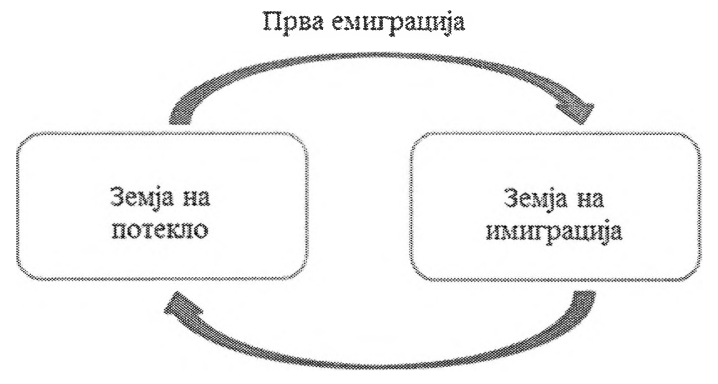

Правец на повратна миграпија

Слика 2: Повратна емиграција (втора категорија)

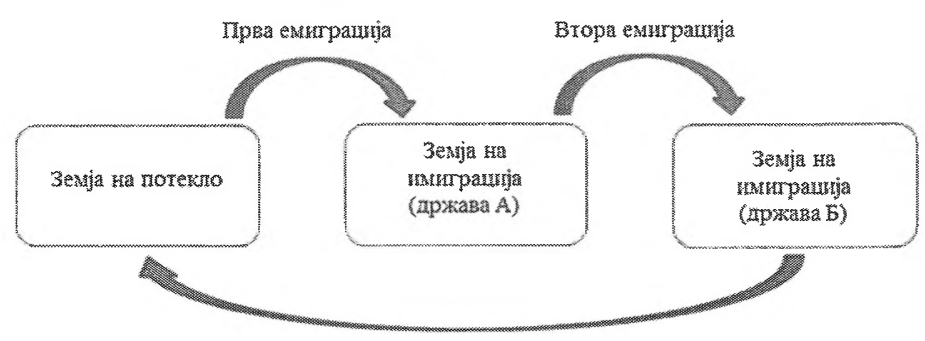

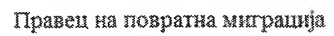

Слика 3: Повратна емиграција (трета категорија)

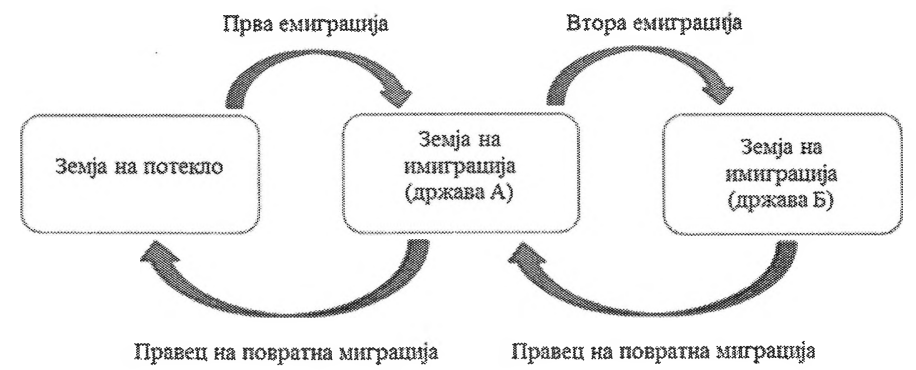

${ }^{2}$ Идејата за сликите е презема од Jean-Christophe Dumont and Gilles Spielvogel, Op.cit. 
Повратната миграција од првата категорија, која е предмет на интерес на овој труд, е карактеристична за прекуокеанските иселеници, додека, пак, останатите две категории ја практикуваат повеќ европските иселеници, поради блиската географската положба на земјите во Европа. Во истражувањето презентирано во продолжение беа застапени иселеници-повратници од САД и од Европа еднакво, но поради малиот број испитаници немаше диверзификација во однос на горенаведените категории повратна миграција.

\section{Иселеници-повратници во Република Македонија}

Истражувањето на иселениците-повратници во Македонија беше спроведено во две временски етапи: првата низа интервјуа беа водени во текот на август и септември 2015 година, додека останатите се реализираа во април и мај 2016 година. Интервјуата беа структурирани и водени индивидуално според претходно утврден прашалник, поделен на три дела. Првиот дел е фокусиран на социоекономските прилики во Република Македонија пред заминувањето на испитаниците во странство. Овој дел ги истражува причините за иселување (пуш-фактори), структурата на семејството, образованието и работното искуство на испитаниците. Вториот дел се однесува на искуството на иселениците во новата држава, вклучувајќ́ ги причините за изборот на државата (пул-фактори), искуството на приспособување во новата земја, времетраењето на престојот, како и структурата на семејството на испитаниците за време на престојот во странство. Овој дел дополнително опфаќа какви врски иселеникот одржувал со својата земја на потекло и дали за време на престојот стекнал повисок степен на образование и/или нови работни вештини. Третиот и последен дел го анализира периодот по враќањето во Македонија, пред сѐ, причините за враќање во земјата на потекло, промените во Република Македонија и во приватниот живот на иселениците-повратници (професија, структура на семејството, планови за иднината итн.).

Испитаниците, вклучени во истражувањето, беа на возраст од 27 до 40 години, петмина од женски и осуммина од машки пол, од македонска етничка припадност, петмина иселеници се вратени од Соединетите Американски Држави, шестмина од земјите на Европската Унија и двајца се претставници на втората генерација иселеници, исто така, вратени од САД.

Проф. д-р Тодор Чепреганов разликува четири историски периоди или фази на современа емиграција од Македонија: првиот бран е карактеризиран со печалбарството или гурбетчиството, вториот ги опфаќа иселеничките движења предизвикани од Балканските војни и Првата светска војна, третиот период е карактеризиран со масовната емиграција по Втората светска војна и четвртиот период ја опфаќа миграцијата помеѓу шеесеттите и деведесеттите години од минатиот век, односно привремената работна миграција или гастарбајтерство (Чепреганов 2010). Проф. д-р Верица Јаневска, исто така, разликува четири поголеми преселнички движења од Македонија, во зависност дали го вклучува печалбарството и/или иселувањето по осамостојувањето на Република Македонија (Јаневска, 2001). За разлика од нив, проф. д-р Танас Вражиновски прави дополнителна поделба на вториот бран на два периода: од втората половина на 19 век до Илинден- 
ското востание и од Илинденското востание до Балканските војни, а третиот период го смета од поделбата на Македонија до Втората светска војна (Вражиновски, 2005).

Мнозинството испитаници од нашето истражување се иселиле од Македонија по нејзиното осамостојување во 1991 година и, според историската поделба на миграциите на македонското население, тие спаѓаат во петтиот историски период и ги потврдуваат карактеристичните причини за иселување од нашата држава во таа фаза: економски причини, нестабилна политичка, општествена и сигурносна констелација во државата, привремена мобилност поради студии во странство, семејно соединување и, конечно, потрага по нови можности и искуства (Avirovic, 2010).

Поголемиот број испитаници заминале во странство поради можноста која им се укажала, односно добивањето зелена карта ${ }^{3}$ за преселба во Соединетите Американски Држави. Иако во Македонија имале веќе работа со средни примања, сепак, по консултации со пријатели и роднини кои веќе живееле во САД, одлучиле да си ја пробаат среќата.

Теоретичарите од областа на миграции потврдуваат дека повеќето иселеници се преселуваат во оние држави каде што имаат веќе пријатели или членови од семејството, формирајќи на таков начин транснационални миграциски мрежи. Овие мрежи на познајници ја поттикнуваат миграцијата со доставување корисни информации, финансирање на патот или позајмување пари на новите иселеници и помагање при доселувањето со тоа што им нудат привремено сместување, им помагаат во наоѓање работа или друг вид економска или социјална помош (Koser, 2007). Македонските иселеници во прекуокеанските земји, за разлика од Европа, имаат традиција на формирање македонски колонии уште од времето на печалбарството (Христов, 2007). Конкретно за американскиот случај, иселувањето ја следи вообичаената шема карактеристична за македонските иселеници уште од времето на печалбарството: првично заминување кај пријатели или роднини, потоа учење или усовршување на англискиот јазик, физичка работа (најчесто не по струка) во фабрики, компании за изнајмување автомобили, ресторани и слично, акумулирање почетен капитал за осамостојување од роднините или пријателите, евентуална доквалификација за признавање на студиите или за стекнување нови вештини и потрага по работа со подобри услови и соодветна на квалификациите. Сепак, меѓу нив има иселеници за кои заминувањето во странство било единствено решение на нивната безизлезна економска состојба, или според зборовите на еден испитаник од машки пол „едно утро мајка ми ми кажа дека нема пари за автобус и дека треба да се шверцам за да стигнам до факултет, [...] тогаш сфатив дека треба нешто да направам“. 4 37-годишниот скопјанец, тогаш 21 -годишен, живе-

\footnotetext{
3 Зелена карта или Green Card е документ кој дава овластување за постојан престој и работа во САД. Нејзината употреба станува практика во САД по Втората светска војна и во текот на годините овој документ има сменето повеќе називи и бои.

${ }^{4}$ Исказите на интервјуираните лица не се коригирани со цел да се задржи нивната оригиналност. Поради тоа, некои од нив може да содржат жаргонски јазик или дијалектни зборови.
} 
ел со својата самохрана мајка која откако останала технолошки вишок, немала начин да го прехрани семејството. Поради семејната финансиска криза, тој решил да замине со позајмени пари на брод и по две сезони работа успеал да добие туристичка виза и останал во САД каде што продолжила неговата печалбарска приказна.

Што се однесува до испитаниците кои заминале на студии или доквалификација во некоја од земјите-членки на ЕУ, причините за привремено иселување се разновидните студиски програми во странство кои биле недостапни во Македонија во моментот на нивното заминување. Една испитаничка единствено била иселена привремено заради работно усовршување. За разлика од иселениците од САД, кои заминале во странство со претходно определен долгорочен план (добивање пасош, акумулирање капитал, работа онолку години потребни за право на пензија во амерканскиот систем), за групата студенти-иселеници студирањето била единствената причина и план. Секако, за некои од овие иселеници престојот бил подолг од предвиденото, најчесто поради работа или продолжување на повисок степен на студии.

Изборот на земјата за оваа група иселеници речиси секогаш е диктирана според изборот на студиите или, пак, можноста за добивање стипендија. Мнозинството иселеници се стекнале со нови вештини и знаења, дури и оние што не заминале во странство заради студии. Една испитаничка, преселена во САД во 2008 година заедно со својот сопруг, иако била веќе дипломиран хемиски инженер, одлучила да се стекне со стручни сертификати поради вработување во болница. Во таа насока, еден иселеник-повратник од САД истакнува дека Соединетите американски држави нудат можности за унапредување во професијата и во поодминати години и како пример ја цитира својата мајка која станала медицинска сестра на 50-ина години.

Генерално, искуството на испитаниците во странство било позитивно: живот во космополитска средина, добра заработувачка, повеќе можности за професионален напредок, повисок животен стандард итн. Сепак, овие иселеници решиле да се вратат. Иако тоа се индивидуални случаи и не може да зборуваме за статистички релевантен примерок, анализата на причините за вракањето во земјата на потекло откриваат интересни сознанија за миграциските истражувања.

Најчести причини за враќае во Македонија беа посочени: подобар квалитет на животот во Македонија (ова се однесува поконкретно на социјалниот живот, месечните трошоци, поточно пониски издатоци за здравствено осигурување и данок на недвижности, особено во споредба со САД), потреба од промени во животот, продолжување на семеен бизнис, носталгија за родителите, основање свое семејство итн. Покрај овие општи причини, во случајот на иселениците-повратници од втора генерација мигранти, враќаето во Македонија претставувало еден вид потрага по сопствените корени, а е поврзано и со нивните постдипломски студии кои во Македонија, кои чинат многу помалку во споредба со оние во САД. Нивниот случај е дополнително специфичен бидејќ контактите со Македонија за време на нивниот живот во странство, пред сѐ, биле поврзани со активностите на македонската дијаспора и спорадични посети на Македонија низ годините. 
Покрај горенаведените пул-фактори за враќање во Македонија, останати пуш-фактори од земјите во странство биле: економската криза од 2008 година во САД и во ЕУ, чувството на граѓани од втор ред (иако тоа претставува индивидуална перцепција, сепак, мнозинството испитаници имале негативно искуство како странци во туѓa држава или посочија пример за такво искуство на некој близок пријател или роднина; единствено една испитаничка не почувствувала дискриминација од никаков вид), како и влијанието од други истакнати Македонци (конкретно, беа посочени министерот за странски инвестиции во Република Македонија, Џери Наумов, и Методија Коловски, претседател на Обединетата македонска дијаспора во САД - ОМД).

Откако се вратиле во Македонија, иселениците-повратници успеале да ги остварат своите планови: основање свое семејство, вработување според квалификациите со дипломите стекнати во странство, продолжување семејни бизниси и отворање нови мали компании. Меѓу нив, највпечатлива е приказната на втора генерација иселеник-повратник на кого му се укажала можност да инвестира во објект во Ресенскиот регион, инаку област на потекло на неговите родители. Иако неговото семејство немало искуство во хотелиерскиот бизнис, во 2012 година отвориле хотел во Отешево, а неговите родители се вратиле во Македонија да му помогнат во раководењето на објектот. Единствено неговата сестра останала да живее во САД. Сега за сега, тој и неговото семејство се задоволни од семејниот бизнис и вели дека секоја година се трудат да ги подобрат условите во хотелот и смета дека и тој и државата Македонија се „на прав пат, со многу сопки“.

Успешна е и приказната на млад иселеник-повратник кој живеел и се образувал во САД од 2001 до 2013 година. Велешанецот по потекло случајно се вратил во Скопје, испратен од компанијата за софтвери за која работел во САД. Во меѓувреме, одлучил да основа веб-страница за алтернативна музика и уметност со што ја исполнил својата желба да го работи тоа што навистина го сака. Смета дека во Македонија со мала заштеда полесно се отвораат мали компании бидејќи ризиците се помали за разлика во САД. Тој вели дека американскиот капиталистички систем е многу суров и не дозволува грешки или, пак, подолг период без работа, бидејќи трошоците за живот се многу високи. Конечно дополнува: „Сите мислат дека надвор од Македонија ги чека мед и млеко, но тоа е само фантазија“.

Единствено една од испитаничките, сопруга на друг иселеник-повратник, немала воопшто желба да се врати во Македонија и кога би можела, би заминала веднаш назад во САД. Други двајца испитаници изразија незадоволство од животот во Македонија во последните неколку години за разлика од првите години по враќањето (соодветно 2010 и 2013). Еден иселеник по нецела година во Македонија повторно се врати во САД на привремен престој за работа. Останатите испитаници немаат конечни планови, но во блиска иднина планираат да останат во Македонија.

Што се однесува до перцепцијата за нашата држава, испитаниците ги поздравуваат сите позитивни промени што настанале во периодот на нивното отсуство, особено воведувањето и спроведувањето на слободната пазарна економија и 
зголемениот број високообразован кадар. Тие сметаат дека со многу напори и уште повеќе промени, Македонија може да стане успешна земја. Сепак, многумина изразија незадоволство од зголемениот сообраќај, бавната бирократија и политичките случувања со кои се соочува Македонија во изминатите години. Најмногу поделени беа мислењата околу изградбата на спомениците во Скопје. За некои испитаници тоа е знак на движење и прогрес, други, пак, сметаат дека наместо спомениците, требало да се изградат фабрики и патишта.

\section{Заклучок}

Појдовната идеја за вакво истражување имаше цел да стави фокус на познати и успешни иселеници-повратници кои се вратиле во Македонија поради основање сопствена компанија или, пак, поради политичка функција. Но, поради недостапноста на мнозинството испитаници од првичната таргет-група (поради чести патувања или логистички причини), фокусот се измени на иселеници-повратници кои немаат јавна функција или не се познати бизнисмени. Дополнително, идејата за овој труд беше да претставува продолжение на претходно квалитативно истражување на студенти иселеници-повратници од 2012 година во кое беа вклучени 28 испитаници (Avirovic, 2012), а да биде претходник на поголемо квантитативно истражување за повратната миграција во Македонија. Помалиот број испитаници од последното истражување, сепак, укажува на тоа дека овој феномен сѐ уште не е доволно распространет во Македонија и не можеме да зборуваме за нов тренд или, пак, општествена појава. Една од причините за намалениот број иселеници-повратници во период од неколку години е веројатно либерализацијата на визниот режим на ЕУ за Македонија од 2010 година, бидејќи како една од главните причини за враќње на студентите повратници од истражувањето од 2012 година беше посочено токму неможноста за регулирање на престојот по студиите.

Сепак, овие индивидуални случаи на иселеници-повратници би ги оцениле како оптимистички, особено во период кога имаме зголемена трајна емиграција на населението од Македонија, како и пораст на апликации за странски патни исправи и документи.

Придонесот од повеќе иселеници-повратници во Македонија секако дека би бил позитивен: од инвестиции во големи компании до зголемен број прилив на мозоци кои се образувале и стекнале професионални вештини во странство. Сепак, остануваат повеќе отворени прашања: од една страна, дали и овие иселенициповратници ќе ги инвестираат своите заштеди во Македонија или ќе ги наменат единствено за изградба на живеалиште и добра кои би им обезбедиле комфорен живот; од друга страна, дали Македонија ќе им го обезбеди барем приближно истиот животен стандард и можности на кои биле навикнати во странство за да не се иселат повторно. 


\section{Литература}

Avirovic, Irena 2010. Patterns of Migration - Patterns of Segregation? A Macedonian Micro-study, Saarbrucken (Germany): VDM Verlag Dr. Muller.

Avirovic, Irena 2012. "Macedonian Post-Socialist Migration" Der Donauraum: Zeitschrift des Institutes für den Donauraum und Mitteleuropa (IDM), 52. Jahrgang, 3-4: 465-481.

Вражиновски, Танас 2005. Иселенички студии, Агенција за иселеништво на Република Македонија, Скопје.

Dumont, J.C., and Spielvogel, G. 2008. Return Migration: A New Perspective, International Migration Outlook, Annual Report, OECD, 2008, стр. 164. Достапно на: https://www.oecd.org/migration/mig/43999382.pdf (15/5/2016)

Јаневска, Верица 2001. Современите мегуународни миграции, емиграчијата од Република Македонија и сочиоекономскиот развој, Економски институт, Скопје.

Koser, Khalid 2007. International Migration. A Very Short Introduction, Oxford University Press, New York.

Lee, Everett S. 1966. A Theory of Migration, Demography, Vol. 3, No. 1.

Lucassen, J., Lucassen, L., and Manning, P. (eds) 2010. Migration History in World History, Multidiciplinary approaches, Studies in Global Social History, Brill, Leiden, Boston.

Moreno, Barry 2004. Encyclopedia of Ellis Island, Greenwood Press, Westport, Connecticut - London.

Seferagić, Dušica, Autumn, 1977. Scientific Work in Yogoslavia on Migrant Returnees and Their Impact on the Mother Country, International Migration Review, Vol. 11, No. 3, The Center for Migration Studies of New York, Inc, стр. 363-374.

Соопштенија за активно население во РМ, Државен завод за статистика на Република Македонија. Достапно на: http://www.stat.gov.mk/PrethodniSoopstenijaOblast.aspx?id $=98 \& \mathrm{rbrObl}=14(10 / 05 / 2016)$

Христов, Стојан 2007. Ова е мојата татковина, Дијалог, Скопје.

Чепреганов, Тодор. Историски фази на миграчиите од Македонија, во Петко Христов (съставител), 2010. Балканската миграчионна култура: исторически и съвременни примери от България и Македония, Българска академия на науките, Етнографски институт с музей, Парадигма, София. 
Irena AVIROVIKJ

\section{RETURN MIGRANTS: NEW PERSPECTIVE OF \\ MIGRATION RESEARCH IN MACEDONIA}

\section{Summary}

Migration flows from the territory of Macedonia have developed and changed throughout different historical periods. After the disintegration of Yugoslavia, migration flows from Macedonia differ significantly from traditional forms of migration. The most characteristic examples are the migration of highly skilled and educated persons or brain drain, migration flows caused by the introduction and liberalization of the visa regime within the European Union and the increased mobility of the population caused mainly by the effects of globalization.

Despite these migratory movements, Macedonia witnesses a reverse migration flow as well, i.e. Return migration in the country of origin. Although the number of return migrants does not exceed those of migrants from Macedonia, this phenomenon, however, has incited our research interest.

This paper will analyze the benefits of returning migrants and their role in the society and it will present several examples of successful migrant returnees and their economic activities in Macedonia. The research, besides the presentation of the qualitative results from a minor study, aims to encourage further research in the area, and to open a debate on the problems of migration in Macedonia.

Keywords: RETURNING EMIGRANTS, MIGRATION, REPUBLIC OF MACEDONIA 